\title{
Insidens dan Faktor Risiko Hipotermia Akibat Memandikan pada Bayi Baru Lahir Cukup Bulan
}

\author{
Irma Rochima Puspita, Rulina Suradi, Zakiudin Munasir
}

Latar belakang. Mandi merupakan salah satu paparan dingin pada bayi baru lahir yang dapat menyebabkan hipotermia. Data mengenai insidens dan faktor risiko hipotermia akibat memandikan bayi baru lahir di Puskesmas atau di rumah bersalin sampai saat ini belum ada. Hasil pengamatan awal yang dilakukan di sebuah Puskesmas dan sebuah rumah bersalin swasta didapatkan sebesar 50\% bayi baru lahir mengalami hipotermia sesudah mandi.

Tujuan Penelitian. Penelitian ini bertujuan untuk mengetahui insidens dan faktor risiko hipotermia akibat memandikan pada bayi baru lahir cukup bulan setelah mendapatkan penyuluhan tentang hipotermia.

Metoda. Penelitian ini adalah studi kohort prospektif pada bayi baru lahir cukup bulan dan sehat yang dimandikan saat usia lebih dari 6 jam. Bayi dimandikan dengan cara seluruh tubuh bayi dibasahi dengan air hangat dan dibersihkan dengan sabun bayi, kemudian seluruh tubuh bayi dimasukkan ke dalam bak mandi. Suhu aksila tubuh diukur dengan termometer digital. Suhu ruangan diukur dengan termometer digital, suhu air mandi diukur dengan termometer air raksa dan lama mandi diukur dengan stopwatch. Sebelum penelitian berlangsung, kepada petugas kesehatan setempat telah diberikan penyuluhan mengenai hipotermia dan persiapan mandi yang baik.

Hasil. Subyek penelitian adalah 100 bayi terdiri dari 53 bayi lahir di Puskesmas dan 47 bayi lahir di RB swasta. Insidens hipotermia di Puskesmas lebih tinggi yaitu sebesar 49\% dibandingkan dengan insidens di RB swasta sebesar 25,5\% (RR 1,79; IK 95\% 1,07; 3,00, p $=0,016)$. Insidens hipotermia pada bayi yang dimandikan pagi hari lebih sering $(44 \%)$ dibandingkan dengan yang dimandikan sore hari $(28 \%)$, namun secara statistik tidak bermakna $(\mathrm{RR}=1,57$; IK 95\% $=0,88 ; 2,79, p=0,107)$. Faktor risiko hipotermia adalah suhu aksila segera sebelum mandi $(r=0,73, p=0,000)$ dan suhu air mandi $(r=0,73, p=$ 0,008 ). Suhu aksila segera sebelum mandi dan suhu air mandi yang aman untuk memandikan bayi baru lahir berusia lebih dari 6 jam adalah berturut-turut $37,25^{\circ} \mathrm{C}$ dan $35^{\circ} \mathrm{C}$.

Kesimpulan. Terjadi penurunan insidens hipotermia setelah mendapatkan penyuluhan tentang persiapan mandi yang baik, dari 50\% pada awal pengamatan menjadi sebesar $49 \%$ di Puskesmas dan $25,5 \%$ di rumah bersalin swasta. Faktor risiko yang berkorelasi dengan hipotermia akibat memandikan bayi cukup bulan lebih dari 6 jam sesudah lahir adalah suhu aksila segera sebelum mandi dan suhu air mandi. Suhu aksila segera sebelum mandi dan suhu air mandi yang aman untuk mencegah hipotermia adalah berturut-turut masing-masing $37,25^{\circ} \mathrm{C}$ dan $35^{\circ} \mathrm{C}$.

Kata kunci: hipotermia, termoregulasi, infant bathing, umur kehamilan

\footnotetext{
Alamat korespondensi:

Prof. Dr. Rulina Suradi, Sp.A(K).

Divisi Perinatologi. Departemen Ilmu Kesehatan Anak FKUI-RSCM.

Jl. Salemba no. 6. Jakarta 10430. Telepon: 021- 3154020
} 
$\mathcal{H}$ potermia merupakan salah satu penyebab utama tingginya angka morbiditas dan mortalitas bayi baru lahir. ${ }^{1,2}$ Hipotermia pada bayi baru lahir disebabkan belum sempurnanya pengaturan suhu tubuh bayi, maupun pengetahuan yang kurang tentang pengelolaan bayi baru lahir yang benar. Pengaturan suhu tubuh bayi baru lahir sangat penting untuk kelangsungan hidup dan mencegah terjadinya hipotermia. ${ }^{1-3}$ Hipotermia pada bayi baru lahir mempengaruhi metabolisme tubuh dan dapat mengakibatkan komplikasi hipoglikemia, asidosis metabolik, distres pernapasan, dan infeksi. ${ }^{4-6}$

Hipotermia terjadi apabila suhu tubuh di bawah $36,5^{\circ} \mathrm{C}$. Hipotermia terjadi akibat ketidakseimbangan antara produksi panas dan kehilangan panas. ${ }^{1,4}$ Kehilangan panas pada bayi baru lahir dapat melalui 4 cara yaitu evaporasi, konduksi, radiasi, dan konveksi. Kesalahan penanganan sesudah lahir dapat menyebabkan bayi baru lahir kehilangan panas akibat keempat cara tersebut. ${ }^{1,3-7}$

Mandi merupakan salah satu paparan dingin pada bayi baru lahir. ${ }^{1,4-6}$ Alasan memandikan bayi baru lahir antara lain berhubungan dengan budaya, estetika, pencegahan penularan penyakit melalui darah atau cairan amnion, dan mengurangi kolonisasi mikroba. ${ }^{7-}$ ${ }^{9} \mathrm{WHO}$ menyarankan bahwa waktu memandikan bayi baru lahir cukup bulan dan sehat dilakukan setelah bayi berusia lebih dari 6 jam. ${ }^{1}$

Hasil pengamatan awal pada sebuah Puskesmas dan rumah bersalin swasta mendapatkan insidens hipotermia pada kedua tempat tersebut adalah sebesar 50\%. Peneliti kemudian memberikan penyuluhan tentang hipotermia dan persiapan mandi yang baik untuk mencegah hipotermia. Tujuan penelitian untuk mengetahui insidens hipotermia dan faktor-faktor yang mempengaruhinya pada bayi baru lahir cukup bulan yang dimandikan lebih dari 6 jam sesudah lahir, setelah mendapatkan penyuluhan persiapan mandi yang baik.

\section{Metoda Penelitian}

Penelitian ini adalah studi observasional kohort prospektif. Tempat penelitian adalah Puskesmas di Jakarta Selatan dan rumah bersalin (RB) swasta di Jakarta Timur. Penelitian ini dilakukan pada Januari 2006 sampai dengan Maret 2006. Kriteria inklusi penelitian, bayi baru lahir cukup bulan dan sehat, usia gestasi 37-
42 minggu, lahir spontan pervaginam, nilai Apgar 1 dan 5 menit pertama ${ }^{3} 7$ (tidak memerlukan resusitasi aktif), berat lahir 2500-4000 gram. Bayi yang mengalami asfiksia perinatal, infeksi, distres pernafasan, hipoglikemia, kelainan bawaan, dan bayi dengan kelainan ibu seperti diabetes melitus, ketuban pecah dini lebih dari $24 \mathrm{jam}$, demam lebih dari $38^{\circ} \mathrm{C}$ sebelum persalinan, proses persalinan SC/EV/EF/sungsang, tidak diikut sertakan dalam penelitian. Persiapan mandi yang baik meliputi suhu tubuh bayi segera sebelum mandi lebih dari $36,5^{\circ} \mathrm{C}$, usia saat mandi lebih dari 6 jam, suhu air mandi hangat, lama mandi singkat (kurang dari 2 menit), suhu ruang mandi dan suhu lingkungan bayi hangat (lebih dari $25^{\circ} \mathrm{C}$ ).

Bayi setelah lahir diletakkan di bawah lampu pijar, jalan napas dibersihkan, dikeringkan, dinilai $A P G A R$ score, dibungkus dengan satu lapis kain hangat, kemudian bayi diletakkan di dalam inkubator. Setelah berusia lebih dari 6 jam, bayi dimandikan dengan cara seluruh tubuh bayi dibasahi dengan air hangat dan dibersihkan dengan sabun bayi, kemudian seluruh tubuh bayi dimasukkan ke dalam bak mandi. Semua bayi setelah dimandikan segera dikeringkan dengan handuk kering, kemudian seluruh tubuh dibungkus dengan satu lapis kain hangat, kecuali bagian kepala bayi. Bayi kemudian diletakkan di dalam inkubator atau di ruang bayi. Suhu aksila dipantau segera sesudah mandi, 10, 30, dan 60 menit setelah mandi menggunakan termometer digital yang ditempatkan di bawah aksila dengan cara merapatkan lengan atas ke tubuh bayi. Suhu ruangan diukur dengan termometer digital, suhu air mandi diukur dengan termometer air raksa dan lama mandi diukur dengan stopwatch.

Peneliti menetapkan bahwa tingkat kemaknaan a= 0,05 dan power penelitian $80 \%$, maka berdasarkan perhitungan besar sampel dibutuhkan jumlah sampel sebesar 31 bayi. Seluruh data yang diperoleh diolah secara statistik dengan menggunakan program komputer SSPS versi 12 for windows. Hubungan antar dua variabel nominal diuji dengan uji $\mathrm{x}^{2}$, sedangkan hubungan antara variabel nominal dan numerik diuji dengan uji $\mathrm{t}$ independen. Untuk menilai hubungan antara berbagai variabel faktor risiko dengan hipotermia digunakan analisis regresi multivariat. Penentuan titik potong suhu air mandi dan suhu aksila bayi segera sebelum mandi yang aman untuk mencegah hipotermia menggunakan Receiver Operator Curve (ROC). 


\section{Hasil Penelitian}

Selama kurun waktu penelitian didapatkan 100 bayi baru lahir yang memenuhi kriteria inklusi yang terdiri dari 53 bayi lahir di Puskesmas dan 47 bayi lahir di Rumah Bersalin swasta.

Pada Tabel 1 tertera bahwa tidak terdapat perbedaan dalam hal status paritas ibu, jenis kelamin bayi, penghangatan sebelum mandi maupun waktu mandi bayi, antara kelompok bayi di Puskesmas dengan kelompok bayi di rumah bersalin swasta.

Rerata suhu ruang mandi antara kelompok Puskesmas dan kelompok rumah bersalin swasta tidak terdapat perbedaan bermakna. Rerata usia saat

Tabel 1. Sebaran karakteristik menurut kelompok penelitian

\begin{tabular}{lcc}
\hline Karakteristik & \multicolumn{2}{c}{ Kelompok } \\
\cline { 2 - 3 } & Puskesmas & RB swasta \\
\hline Paritas ibu & 16 & 21 \\
$\quad$ Primipara & 37 & 26 \\
$\quad$ Multipara & & \\
Jenis kelamin bayi & 31 & 22 \\
$\quad$ Laki-laki & 22 & 25 \\
$\quad$ Wanita & & \\
Penghangatan sebelum mandi & 53 & 46 \\
$\quad$ Inkubator & 0 & 1 \\
$\quad$ Tanpa inkubator & & \\
Saat memandikan bayi & 30 & 31 \\
$\quad$ Pagi & 23 & 16 \\
$\quad$ Sore &
\end{tabular}

mandi, rerata suhu aksila segera sebelum mandi, rerata suhu aksila bayi sesudah mandi dan suhu air mandi pada kelompok puskesmas lebih rendah dibandingkan dengan kelompok rumah bersalin swasta. Lama mandi pada kelompok Puskesmas lebih lama dibandingkan dengan kelompok rumah bersalin swasta dan perbedaan ini bermakna secara statistik (Tabel 2).

Rerata suhu aksila bayi sesudah mandi pada bayi yang lahir di rumah bersalin swasta lebih tinggi dibandingkan dengan rerata suhu aksila bayi yang lahir di puskesmas. Suhu aksila minimum dan suhu aksila maksimum bayi segera sesudah mandi di rumah bersalin swasta juga lebih tinggi dibandingkan dengan suhu aksila bayi di Puskesmas (Gambar 1).

Secara keseluruhan insidens hipotermia akibat memandikan bayi baru lahir cukup bulan dan sehat lebih dari 6 jam sesudah lahir adalah sebesar 38\%. Insidens hipotermia akibat memandikan bayi baru lahir cukup bulan dan sehat lebih dari 6 jam sesudah

Tabel 3. Insidens hipotermia sesudah mandi menurut kelompok

\begin{tabular}{lllr}
\hline \multirow{2}{*}{ Kelompok } & \multicolumn{2}{c}{ Hipotermia (\%) } & \multirow{2}{*}{ Jumlah } \\
\cline { 2 - 3 } & Positip & Negatip & \\
\hline Puskesmas & $26(49)$ & $27(51)$ & 53 \\
RB swasta & $12(25,5)$ & $35(74,5)$ & 47 \\
Jumlah & $38(38)$ & $62(62)$ & 100 \\
\hline
\end{tabular}

$p=0,016 \quad \mathrm{RR}=1,79 \quad$ IK $95 \%=1,07 ; 3,00$

Tabel 2. Rerata dan simpang baku (SB) variabel mandi menurut kelompok

\begin{tabular}{lccccc}
\hline Variabel mandi & \multicolumn{2}{c}{$\begin{array}{c}\text { Puskesmas } \\
(\mathbf{n}=53)\end{array}$} & \multicolumn{3}{c}{$\begin{array}{c}\text { RB swasta } \\
(\mathbf{n}=47)\end{array}$} \\
\cline { 2 - 6 } & Rerata & SB & Rerata & SB & \\
\hline Usia saat mandi $\left.{ }^{*}\right)$ (jam) & 10,3 & 3,5 & 12,1 & 3,4 & 0,014 \\
Suhu aksila pra mandi $\left({ }^{\circ} \mathrm{C}\right)$ & 37,1 & 0,4 & 37,3 & 0,4 & 0,002 \\
Lama mandi $\left.{ }^{\circ}\right)($ detik) & 152,0 & 61,8 & 70,8 & 21,7 & 0,000 \\
Suhu air mandi $\left({ }^{\circ} \mathrm{C}\right)$ & 34,2 & 1,8 & 36,6 & 1,5 & 0,000 \\
Suhu ruang mandi $\left({ }^{\circ} \mathrm{C}\right)$ & 28,9 & 1,5 & 29,0 & 1,5 & 0,788 \\
Suhu aksila segera setelah mandi $\left({ }^{\circ} \mathrm{C}\right)$ & 36,9 & 0,6 & 37,1 & 0,5 & 0,030 \\
Suhu aksila 10'sesudah mandi $\left({ }^{\circ} \mathrm{C}\right)$ & 36,6 & 0,5 & 36,9 & 0,5 & 0,001 \\
Suhu aksila 30' sesudah mandi $\left({ }^{\circ} \mathrm{C}\right)$ & 36,7 & 0,4 & 37,0 & 0,5 & 0,002 \\
Suhu aksila 60' sesudah mandi $\left({ }^{\circ} \mathrm{C}\right)$ & 36,7 & 1,0 & 37,1 & 0,5 & 0,043 \\
\hline
\end{tabular}

Ket: *) Uji Mann Whitney Rank

Pra : segera sebelum mandi

Post : segera sesudah mandi 
lahir di puskesmas lebih tinggi yaitu sebesar 49\% dibandingkan dengan insidens hipotermia di rumah bersalin swasta yaitu sebesar $25,5 \%$ dan bermakna secara statistik (RR 1,79; IK 95\% 1,07; 3,00,p = 0,016) (Tabel 3). Insidens hipotermia akibat memandikan bayi baru lahir lebih dari 6 jam sesudah lahir lebih banyak pada waktu pagi hari sebesar $44 \%$ dibandingkan dengan sore hari yaitu sebesar $28 \%$, namun secara statistik tidak berbeda bermakna $(\mathrm{RR}=1,57$; IK $95 \%=0,88 ; 2,79, p=0,107)$.

Analisis regresi multivariat menunjukkan bahwa faktor risiko hipotermia pada bayi baru lahir cukup bulan yang dimandikan lebih dari 6 jam sesudah lahir adalah suhu aksila bayi segera sebelum mandi dan suhu air mandi dengan korelasi yang kuat $(r=0,73)$ dan bermakna secara statistik.

Suhu aksila segera sebelum mandi yang aman sebelum memandikan bayi baru lahir lebih dari 6 jam untuk mencegah hipotermia adalah sebesar $37,25^{\circ} \mathrm{C}$. Suhu aksila segera sebelum mandi yang aman untuk mencegah hipotermia pada penelitian ini mempunyai sensitifitas dan spesifisitas sebesar 65\% dan 68\% (Gambar 2).

Suhu air mandi yang aman untuk memandikan bayi baru lahir lebih dari 6 jam untuk mencegah hipotermia adalah sebesar $35^{\circ} \mathrm{C}$. Suhu air mandi yang dapat digunakan untuk mencegah hipotermia pada penelitian ini mempunyai sensitifitas dan spesifisitas sebesar 61\% dan 66\% (Gambar 3).

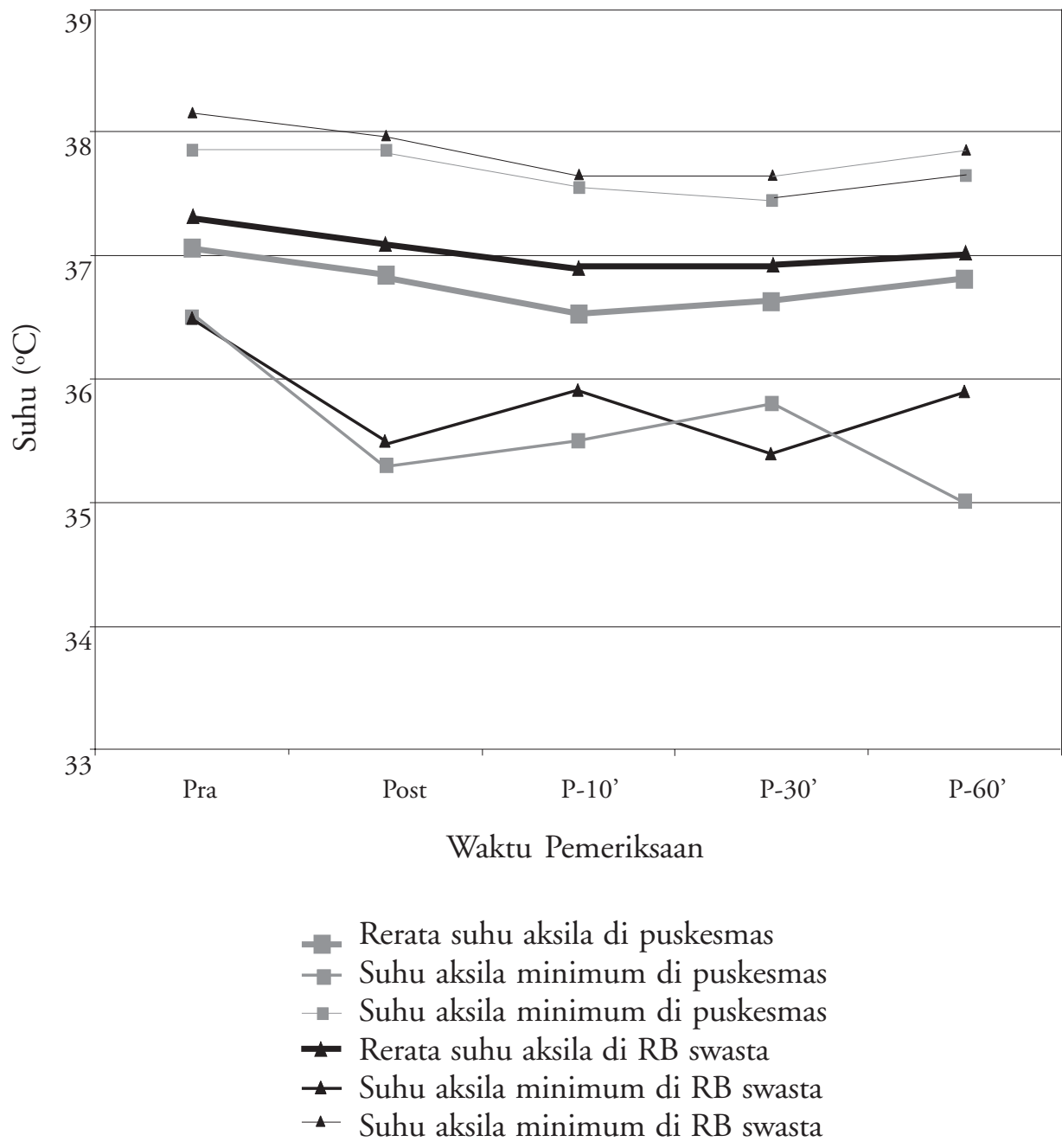

Gambar 1. Pola suhu aksila bayi sebelum dan sesudah mandi 


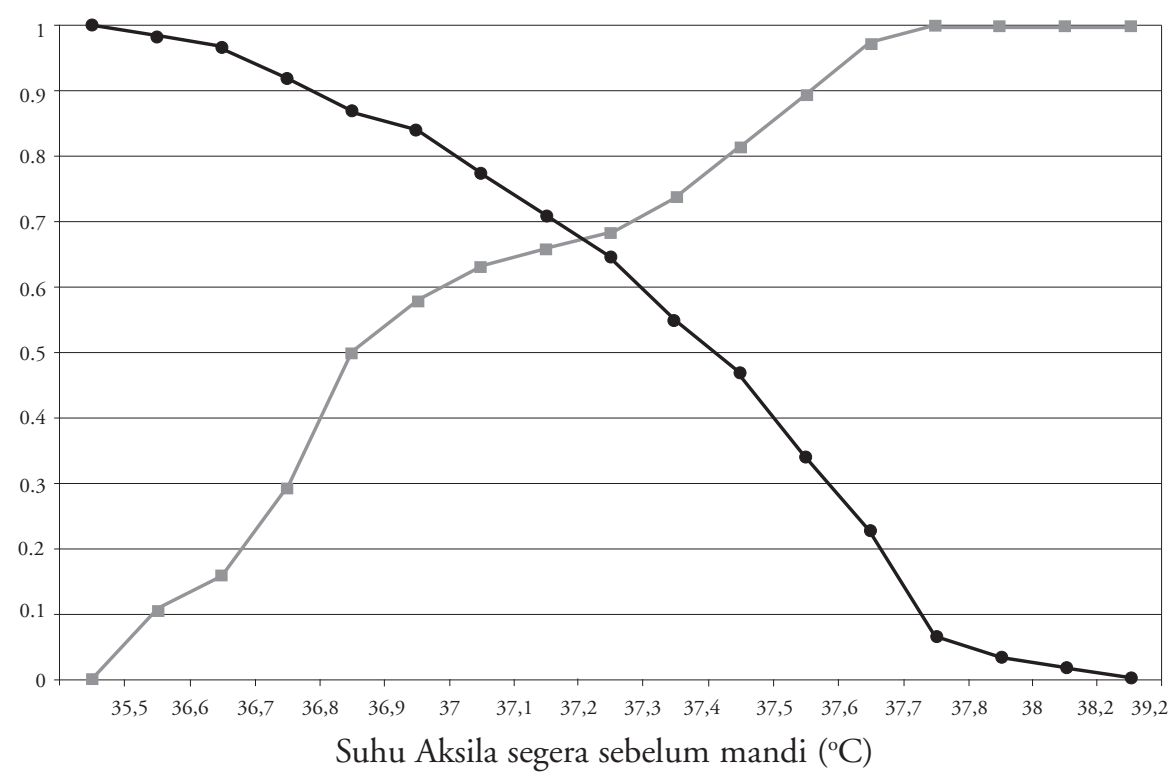

$\rightarrow$ Sensitifitas - - Spesifisitas

Gambar 2. Grafik titik potong suhu aksila bayi segera sebelum mandi

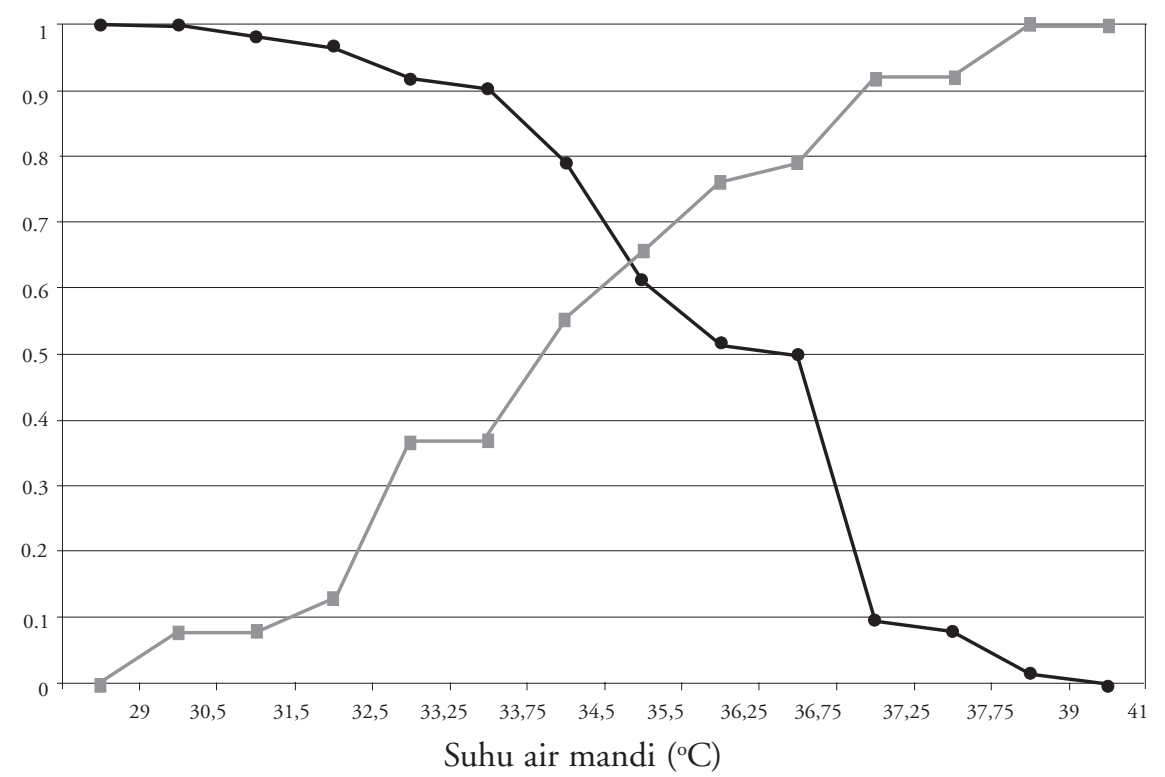

Sensitifitas $\_$Spesifisitas

Gambar 3. Grafik titik potong suhu air mandi

\section{Pembahasan}

Pada penelitian Nako $\mathrm{dkk}^{10}$ didapatkan insidens hipotermia pada bayi baru lahir yang dimandikan 2-5 menit sesudah lahir sebesar $2,1 \%$. Gunawijaya ${ }^{11}$ melaporkan insidens hipotermia pada bayi baru lahir cukup bulan yang dimandikan 10 menit sesudah lahir $6,8 \%$, sedangkan yang dimandikan 2-6 jam sesudah lahir $1,5 \%$.

Insidens hipotermia pada saat awal pengamatan 
di kedua tempat penelitian 50\%. Pada penelitian ini insidens hipotermia akibat memandikan bayi baru lahir cukup bulan dan sehat lebih dari 6 jam sesudah lahir setelah mendapatkan penyuluhan tentang persiapan mandi yang baik secara keseluruhan 38\%. Insidens hipotermia di Puskesmas lebih tinggi 49\% dibandingkan dengan insidens hipotermia di rumah bersalin swasta $25,5 \%$.

Pada penelitian ini rerata suhu aksila bayi sesudah mandi di rumah bersalin swasta lebih tinggi dibandingkan dengan kejadiannya di Puskesmas. Hal ini menunjukkan bahwa persiapan mandi di rumah bersalin swasta lebih baik dibandingkan dengan di Puskesmas. Perbedaan ini disebabkan jumlah bidan di rumah bersalin swasta lebih banyak dan jumlah bidan yang mendapatkan pelatihan Asuhan Persalinan Normal (APN) juga lebih banyak dibandingkan dengan jumlah bidan di Puskesmas. Pelatihan APN juga mencakup pengelolaan bayi baru lahir yang benar, termasuk cara memandikan bayi baru lahir yang benar.

Gunawijaya $\mathrm{dkk}^{11}$ melaporkan bahwa penurunan suhu tubuh bayi sesudah mandi terjadi pada menit kelimabelas $0,15^{\circ} \mathrm{C}$. Pada penelitian Takayama $\mathrm{dkk}^{12}$ penurunan suhu tubuh bayi sesudah mandi terjadi pada menit ketigapuluh sebesar $0,2^{\circ} \mathrm{C}$. Pada penelitian ini, kelompok bayi yang persiapan mandinya lebih baik (di rumah bersalin swasta) mengalami penurunan suhu aksila segera sesudah mandi sebesar $0,2^{\circ} \mathrm{C}$ dan pada menit kesepuluh sebesar $0,4^{\circ} \mathrm{C}$. Sedangkan pada kelompok bayi di Puskesmas, penurunan suhu aksila segera sesudah mandi sebesar $0,2^{\circ} \mathrm{C}$ dan pada menit kesepuluh sebesar $0,5^{\circ} \mathrm{C}$.

Pencapaian suhu tubuh normal kembali pada bayi baru lahir cukup bulan sesudah mandi menurut Medves $\mathrm{dkk}^{13}$ adalah 1 jam sesudah mandi, menurut Varda $\mathrm{dkk}^{14}$ adalah 1-2 jam sesudah mandi dan menurut Takayama ${ }^{12}$ adalah 2-3 jam sesudah mandi. Sedangkan Gunawijaya ${ }^{11}$ melaporkan bahwa pencapaian suhu tubuh bayi normal kembali sesudah mandi pada menit ketigapuluh. Pencapaian suhu tubuh bayi normal kembali sesudah mandi pada penelitian ini sesuai dengan penelitian Gunawijaya yaitu pada menit ketigapuluh.

Faktor-faktor risiko yang dapat mempengaruhi terjadinya hipotermia akibat memandikan bayi cukup bulan dan sehat pada usia lebih dari 6 jam sesudah lahir meliputi usia saat mandi, suhu tubuh segera sebelum mandi, suhu air mandi, lama waktu mandi, suhu ruang mandi dan suhu lingkungan bayi. ${ }^{1,11-15} \mathrm{Pada}$ penelitian ini lama waktu mandi, suhu ruang mandi dan suhu lingkungan bayi tidak mempunyai hubungan yang bermakna secara statistik dengan insidens hipotermia. Faktor risiko hipotermia pada penelitian ini adalah suhu aksila segera sebelum mandi dan suhu air mandi.

Pedoman WHO menyatakan bahwa bayi dapat dimandikan setelah suhu tubuhnya normal stabil, namun tidak menyatakan derajat suhu bayi segera sebelum mandi yang aman untuk mencegah hipotermia. ${ }^{1}$ Suhu tubuh bayi baru lahir cukup bulan segera sebelum mandi yang aman menurut Penny $\mathrm{dkk},{ }^{15}$ lebih atau sama dengan $36,5^{\circ} \mathrm{C}$, sedangkan menurut Varda $\mathrm{dkk}^{14}$ lebih atau sama dengan $36,8^{\circ} \mathrm{C}$. Pada penelitian ini didapatkan suhu aksila segera sebelum mandi yang aman untuk mencegah hipotermia $37,25^{\circ} \mathrm{C}$. Hal ini menunjukkan bahwa hipotermia pada penelitian ini juga disebabkan oleh faktor lain.

Suhu air mandi yang digunakan pada penelitian Gunawijaya $^{11}(37-38)^{0} \mathrm{C}$, sedangkan pada penelitian Nako dkk ${ }^{10}(36 \pm 1)^{\circ} \mathrm{C}$. WHO tidak menyatakan derajat suhu air mandi yang aman untuk bayi baru lahir untuk mencegah hipotermia. ${ }^{1}$ Pada penelitian ini didapatkan bahwa suhu air mandi mempunyai hubungan yang bermakna secara statistik dengan kejadian hipotermia $(p=0,008)$. Rerata suhu air mandi yang digunakan di rumah bersalin lebih tinggi $\left(36,6^{\circ} \mathrm{C}, \mathrm{SB} 1,5\right)$ dibandingkan dengan rerata suhu air mandi yang digunakan di Puskesmas $\left(34,2^{\circ} \mathrm{C}, \mathrm{SB}\right.$ $1,8)$. Suhu air mandi yang aman digunakan untuk memandikan bayi baru lahir pada penelitian ini adalah $35^{\circ} \mathrm{C}$. Insidens hipotermia pada penelitian ini lebih tinggi dibandingkan dengan penelitian lain karena suhu air mandi yang digunakan pada penelitian ini lebih rendah dibandingkan dengan penelitian sebelumnya.

Insidens hipotermia pada penelitian Gunawijaya ${ }^{11}$ lebih sedikit dibandingkan dengan penelitian ini karena penelitian Gunawijaya dilakukan di sebuah rumah sakit dengan persiapan mandi yang lebih baik yaitu meliputi mandi dilakukan dalam waktu singkat oleh tenaga kesehatan terlatih, menggunakan air mandi yang suhunya lebih tinggi, sesudah mandi bayi diletakkan di bawah radiant warmer selama 30 menit dan dibungkus dengan kain serta penutup kepala. Penurunan suhu tubuh bayi sesudah mandi pada penelitian sebelumnya lebih sedikit dibandingkan dengan penelitian ini disebabkan perbedaan metoda penghangatan sesudah mandi. ${ }^{10-12,16-18}$ 


\section{Kesimpulan}

Terjadi penurunan insidens hipotermia setelah mendapatkan penyuluhan tentang persiapan mandi yang baik di Puskesmas maupun di rumah bersalin. Faktor risiko yang berhubungan dengan hipotermia akibat memandikan pada bayi cukup bulan berusia lebih dari 6 jam adalah suhu aksila segera sebelum mandi dan suhu air mandi. Suhu aksila sebelum mandi dan suhu air mandi yang aman bagi bayi baru lahir cukup bulan masing-masing adalah $37,25^{\circ} \mathrm{C}$ dan $35^{\circ} \mathrm{C}$.

\section{Daftar Pustaka}

1. World Health Organization. Thermal protection of the newborn: a practical guide. WHO/RTH/MSM/97.2.

2. Ellis M, Manandhar N, Shakya U, Manandhar DS, Fawdry A, Costello AM. Postnatal hypothermia and cold stress among newborn infants in Nepal monitored by continous ambulatory. Arch Dis Child 1996; 75:42-5.

3. Christensson K, Arvidson ABR, Kakoma C, Lungu F, Darkwah G, Chikamata D, dkk. Midwifery care routines and prevention of heat loss in the newborn: a study in Zambia. J Trop Pediatr 1988; 34:208-12.

4. Gomella TL. Temperature regulation. Dalam: Gomella, Cunningham MD, Eyal FG, Zenk KE, penyunting. Neonatology: management, procedures, on-cal problems, diseases and drugs. New York: Lange Medical Books, 1999. h. 38-42.

5. Askin DF. Complication in the transition from fetal to neonatal life. J Obstet Gynecol Neonatal Nurs 2001; 31:318-27.

6. Blackburn ST. Thermoregulation. Dalam: Blackburn ST, Loper DL, penyunting. Maternal, fetal, and neonatal physiology: a clinical perspective. Philadelphia: WB Saunders Company, 1992. h. 677-97.
7. American Academy of Pediatrics. Committee on fetus and newborn: skin care of newborns. Pediatrics 1974; 54:682-3.

8. Lund CH, Osborn JW, Kuller J, Lane AT, Lott JW, Raines DA. Neonatal skin care: the scientific basis for practice. J Obstet Gynecol Neonatal Nurs 1999; 28:24154.

9. Medeves JM, O’Brien B. Does bathing newborns remove potentially harmfull pathogens from the skin? Birth 2001; 28:161-5.

10. Nako Y, Harigaya A, Tomomasa T, Morikawa A, Amada M, Kijima C, dkk. Effect of bathing immediately after birth on early neonatal adaptation and morbidity: a prospective randomized comparative study. Pediatrics International 2000; 42:517-22.

11. Gunawijaya E, Hamid A. Changes in temperature of newborn babies bathed immediately after birth. Med J Indones 2003; 12:73-80.

12. Takayama JI, Teng W, Uyemoto J, Newman TB, Pantel RH. Body temperature of newborn: what is normal? Clin Pediatr 2000; 39:503-10.

13. Medves JM, O'Brien B. The effect of bather and location of first bath on maintaining thermal stability in newborns. J Obstet Gynecol Neonatal Nurs 2004; 33:175-82.

14. Varda KE, Behnke RS. The effect of timing of initial bath on newborn's temperature. J Obstet Gynecol Neonatal Nurs 2000; 29:27-32.

15. Penny MGT. Newborn $\phi_{s}$ first bath: when? J Obstet Gynecol Neonatal Nurs 1996; 25:481-7.

16. Stothers JK. Head insulation and heat loss in the newborn. Arch Dis Child 1981; 56:530-4.

17. Cusson, Regina M, Madonia, Joyce A, Taekman, Jeanne B. The effect of environment on body site temperatures in full-term neonates. Nurs Res 1997; 46:202-7.

18. Medves JM, O'Brien B. The effect of bather and location of first bath on maintaining thermal stability in newborns. J Obstet Gynecol Neonatal Nurs 2004; 33:175-82. 